\title{
AL-IQTISHADIYAH
}

Jurnal Ekonomi Syariah dan Hukum Ekonomi Syariah

E-ISSN: 2621-0274; P-ISSN: 2442-2282

Volume 7, Nomor 1, Juni 2021

\section{Restrukturisasi Sebagai Sarana Negosiasi pada Pembiayaan Macet Jual Beli Angsuran di BMT IKPM Ponorogo}

\author{
May Shinta Retnowati ${ }^{1}$, Muhammad Ulul Azmi ${ }^{2}$, \& Hifdhotul Munawaroh ${ }^{3}$ \\ 1 Fakultas Syariah, Universitas Darussalam Gontor, Indonesia. E-mail: mayshinta@unida.gontor.ac.id \\ 2 Fakultas Syariah, Universitas Darussalam Gontor, Indonesia. E-mail: \\ muhammadululazmi@unida.gontor.ac.id \\ 3 Fakultas Syariah, Universitas Darussalam Gontor, Indonesia. E-mail: hifdhoh@unida.gontor.ac.id
}

\section{ARTICLE INFO}

Keywords:

Installment buying and selling; Negotiation; Restructuring

\section{Kata Kunci:}

Jual beli angsuran; Negosiasi; Restrukturisasi

\begin{abstract}
This study aims to analyze the efforts made by BMT IKPM Ponorogo to be able to save non -bank financial institutions from non-performing financing in the sale and purchase of installments and customers to settle its obligations. This study used qualitative descriptive with the techniques of collection data through observations, interviews and documentation, then analyzed descriptively. The results of this study show that the settlement of non -performing financing on sale and purchase installment financing in BMT IKPM can be done by conducting negotiations to resolve non -performing financing disputes related to restructuring.
\end{abstract}

\section{ABSTRAK}

Penelitian ini bertujuan untuk menganalisa upaya yang dilakukan oleh BMT IKPM Ponorogo untuk dapat menyelamatkan lembaga keuangan non bank dari pembiayaan macet pada jual beli angsuran dan nasabah agar dapat menyelesaikan kewajibannya. Jenis penelitian ini adalah penelitian kualitatif deskriptif dengan teknik pengumpulan data melalui observasi, wawancara dan dokumentasi, selanjutnya dianalisis secara deskriptif. Hasil penelitian ini menunjukkan penyelesaian pembiayaan macet pada pembiayaan jual beli angsuran di BMT IKPM dapat dilakukan dengan caranegosiasi untuk menyelesaikan perselisihan pembiayaan macet yang bersifat kekeluargaan pada restruksisasi.

\section{Pendahuluan}

Kegiatan usaha pada lembaga keuangan syariah dapat dikelompokkan menjadi tiga macam produk yaitu simpanan (liability based product) seperti bentuk simpanan dan juga tabungan, aset (asset based product) yang berbentuk pembiayaan, dan produk jasa (Service Based Product) seperti transaksi pembayaran, transfer, kliring, dan sebagainya. Dijelaskan dalam UU tentang Perbankan Nomor 10 Tahun 1998, pembiayaan adalah menyediakan dana ataupun tagihan yang dapat dipersamakan bentuknya dengan itu, yang berdasar pada persetujuan ataupun kesepakatan pihak 
bank dan pihak lainnya yang menjadikan pihak yang dibiayai tersebut wajib untuk mengembalikan dana atau tagihan dalam rentang waktu yang ditentukan dengan disertai imbalan ataupun bagi hasil. ${ }^{1}$

Lembaga keuangan syariah bank dan non-bank seperti baitul maal watamwil (BMT) merupakan lembaga intermediary atau lembaga perantara keuangan nasabah dari nasabah surplus dana ke nasabah deficit dana. Pada penyaluran dana ini dilakukan dengan cara angsuran yang terbagi menjadi jenis kredit produktif dan kredit konsumtif. Adapun istilah kredit yang berasal dari kata latin, "credere", "credo" dan "creditum" artinya kepercayaan. Kredit juga dapat dimaknai sebagai suatu perjanjian pinjam-meminjam di lembaga keuangan. Pada lembaga keuangan di Indonesia, pengaturan kredit sendiri terdapat didalam UU No. 10 Tahun 1998 di pasal 1 nomor 11 yang menjelaskan bahwa kredit adalah bentuk peminjaman dana yang diberikan pihak bank ke pihak lain yang sesuai dengan yang telah dijelaskan didalam perjanjian, termasuk hak dan kewajiban pihak lain untuk pembayaran pinjaman tersebut dalam rentang waktu tertentu. ${ }^{2}$

Setelah mendapat pembiayaan dari lembaga keuangan, nasabah pembiayaan tersebut harus melunasinya dengan cara cicil, namun pada suatu kondisi tertentu terkadang nasabah tersebut mengalami kesulitan dalam membayar angsuran yang telah ditetapkan pada perjanjian. Hal ini pula yang akan mengakibatkan kerugian pada pihak lembga keuangan Islam non Bank atau BMT maupun pihak nasabah itu sendiri. Agar dapat meminimalisir risiko-risiko yang terjadi pada pembayaran angsuran macet dan juga agar dapat tercapainya kesejahteraan yang seimbang antara nasabah dan lembaga dalam penyelesaian pembayaran macet maka diperlukan negoisasi atas pemecahan masalah antara nasabah dan lembaga yang bersangkutan supaya dapat mencapai solusi terbaik diantara kedua belah pihak, salah satu caranya yakni dengan sarana restrukturisasi.

Restrukturisasi merupakan istilah teknis yang umumnya dipergunakan pelaku perbankan terhadap upaya dan langkah yang diterapkan pihak bank dalam usaha untuk mengatasi masalah pembiayaan yang sedang dihadapi para debitur yang dianggap masih mempunyai prospek usaha yang baik, namun sedang mengalami kesulitan dalam melakukan pembayaran angsuran pokok ataupun kewajiban yang lain, agar kembali dapat memenuhi kewajibannya dalam melunasi hutang. ${ }^{3}$

Praktik penyelesaian masalah pembiayaan macet yang dilakukan pada lembaga keuangan Islam non-Bank seperti halnya Baitul Maal wa tamwil (BMT) yakni dengan beberapa cara antara lain: 1. perubahan jadwal (Rescheduling), 2. persyaratan

\footnotetext{
${ }^{1}$ Rinda Lidyah, dkk. Pengujian Financing To Deposit Ratio Sebagai Mediasi Antara Pembiayaan Non Performing Financing dan Biaya Operasional Terhadap Laba Pada Bank Umum Syariah di Indonesia, Jurnal I-Finance, Vol.05 No.2 Desember 2019.
}

${ }^{2}$ Ucok Parulianth Simamora, Restrukturisasi Perjanjian Kredit Dalam Perhatian Khusus (Studi Kasus Pada PT.Bank Rakyat Indonessia, TBK Cabang Bandar Jaya Unit Haduyang Ratu), Jurnal Cepalo Vol. 1 No. 12017.

${ }^{3}$ Djamil, Penyelesaian Pembiayaan Bermasalah di Bank Syariah, (Jakarta: Sinar Grafika, 2012), p. 56. 
kembali (Reconditioning), dan 3. penataan kembali (Restructuring). ${ }^{4}$ Adapun mekanisme dari penyelesaian dengan model restrukturing masih belum dipaparkan detail pada tiap bagiannya hanya saja dijelaskan dengan Surat Edaran BI No.10/34/Dpbs 2008 bahwa dalam melaksanakan restrukturisasi pembiayaan Bank Umum Syariah dan Unit Usaha Syariah harus menerapkan prinsip kehati-hatian dan prinsip syariah serta prinsip akuntansi yang berlaku. ${ }^{5}$

Baitul Maal wa tamwil Ikatan Keluarga Pondok Modern (BMT IKPM) pada penyelesaian masalah pembiayaan macet lebih sering menggunakan dan hanya sampai batas restrukturisasi, dan bahkan tidak sampai batas eksekusi jaminan. Hal ini menunjukan suatu kebijakan BMT IKPM untuk dapat meminimalisir risiko dan kerugian-kerugian yang terjadi dari pembiayaan macet dari jual beli angsuran. Restrukturisasi yang mereka gunakan merupakan upaya batas maksimal mereka agar penyelesaian masalah tidak sampai pada eksekusi barang jaminan atau bahkan sampai pada ranah pengadilan. Praktik ini dapat memudahkan para nasabah pembiayaan macet darijual beli angsuran dan BMT IKPM sendiri guna menekan biaya-biaya dan waktu dalam penyelesaian permasalahan tersebut. ${ }^{6}$ Praktis fokus restrukturisasi yang dilakukan BMT IKPM ini lah yang menarik perhatian penulis untuk melakukan kajian khusus terhadapnya.

Penelitian lain yang mengkaji praktik penyelesaian pembiayaan bermasalah sendiri sudah cukup banyaj. Madona Khoirunisa dan Musrifah misalnya, menjelaskan dalam kesimpulannya bahwa pola penyelesaian pembiayaan bermasalah pada Bank syariah dapat dilakukan dengan cara: 1. Restrukturasi, 2. Penyelesaian melalui jaminan, 3. Collection Agent, dan 4. Hapus buku (write off). ${ }^{7}$

Wita Dera Tiranti membahas tentang mekanisme restrukturisasi pembiayaan murabahah di BMT Assyafiiyah Berkah Nasional Adiluwih. la menyimpulkan bahwa mekanisme restrukturisasi yang dilakukan dengan cara perubahan jadwal (Rescheduling), persyaratan kembali (Reconditioning), dan penataan kembali (Restructuring), tetapi konsep Restructuring jarang dilakukan atau digunakan oleh pihak BMT. 8

Penelitian terkait dengan restrukturasi juga dilakukan oleh Abdul Khaliq dan Rizqi Rahmawati, yang melihat dampak implementasi restrukturasi terhadap likuiditas bank syariah pada masa pandemi. Disimpulkan bahwa secara umum tingkat likuiditas

\footnotetext{
${ }^{4}$ Wita Dera Tiranti, Mekanisme Restrukturisasi Pembiayaan Murabahah di BMT Assyafiiyah Berkah Nasional Adiluwih Pringsewu,Skripsi: IAIN Metro, 2019, p. 38.

${ }^{5}$ Surat Edaran BI untuk semua Bank Umum Syariah dan Unit Usaha Syariah di Indonesia No.10/34/Dpbs 2008.

${ }^{6}$ Wawancara, Ahmad Hisanuddin, Finance, September 2020.

${ }^{7}$ Madona Khairunisa dan Musrifah, Penyelesaian Pembiayaan Bermasalah pada Bank Syariah, Jurnal IBF: Islamic Business and Finance, Vol. 1, No. 1, April 2020, p. 79

${ }^{8}$ Wita Dera Tiranti, Mekanisme Restrukturisasi Pembiayaan Murabahah di BMT Assyafiiyah Berkah Nasional Adiluwih Pringsewu, Skripsi: IAIN Metro, 2019
} 
bank syariah dapat dikategorikan sehat atau likuid. ${ }^{9}$ Penelitian serupa juga dilakukan oleh Farhan Asyhadi yang menyimpulkan bahwa upaya restrukturasi harus diikuti juga dengan adanya penilaian ulang yang dilakukan secara lebih mendalam terhadap usaha para debitur, hal ini dimaksudkan agar tidak terjadi pengulangan restrukturasi untuk satu perjanjian hutang dari debitur yang sama. ${ }^{10}$

Berdasarkan penelitian-penelitian terdahulu tersebut, terlihat bahwa ada beberapa persamaan dengan penelitian ini, yakni membahas tentang pembiayaan macet pada praktik murabahah atau jual beli kredit, namun fokus permasalahan yang diteliti berbeda. Penelitian ini lebih fokus pada penyelesaian pembiayaan macet yang hanya mengoptimalkan sampai batas restrukturisasi dengan negoisasi yang digunakan, guna meminalisir risiko yang merugikan salah satu pihak.

\section{Landasan Teori}

\section{Jual Beli Angsuran}

Aktifitas ekonomi Islam tidak lepas dengan nilai-nilai dasar yang sudah diatur di dalam Al-Qur'an, Sunah, Ijma', Qiyas dan juga sumber hukum Islam yang lain. Islam kental dengan nilai-nilai yang memacu manusia agar dapat membangun sistem ekonomi yang bertujuan untuk falah oriented, yang tidak hanya mengoptimalkan keuntungan duniawi saja, akan tetapi keuntungan akhirat. Hal ini terlihat dari praktik yang selalu tepat dan baik untuk diimplikasikan dalam kehidupan aktual dan konsistensinya dalam ajaran-ajaran dari Allah.

Manusia pada hakikatnya adalah makhluk sosial. Manusia tidak dapat mencukupi kebutuhannya seorang diri, melainkan harus melakukan interaksi dengan orang lain. Manusia juga membuthkan bantuan dari orang lain dan diperlukan juga oleh orang lain. Pada interaksi ini maka dibutuhkan suatu aturan yang baik dengan tujuan agar dapat menghindari terjadinya kelalaian, kedzaliman antara mereka, seperti dalam jual-beli. Kegiatan jual-beli ini pada dasarnya sudah lama dikerjakan orang-orang terdahulu. Dalam ajaran Islam kegiatan jual-beli merupakan bagian dari muamalah yang diatur pula oleh agama dan secara sistematis telah diatur rambu-rambu larangan dan kebolehannya. Tujuan dari diaturnya suatu transaksi tidak lain untuk menciptakan kemaslahatan terhadap kegiatan ini, tidak merugikan salah satu pihak dan menghilangkan keburukan atau kebathilan dalam kegiatannya. ${ }^{11}$

Sebagaimana dalam QS AI-Maidah ayat 2 yang berbunyi:

\footnotetext{
${ }^{9}$ Abdul Kholiq dan Rizqi Rahmawati, Dampak Implementasi Restrukturasi Pembiayaan Terhadap Likuiditas Bank Syariah pada Situasi Pandemi Covid-19, el Barka: Journal of Islamic Economic and Business, Vol. 3, No. 2, Juli-Desember 2020, p. 283.

${ }^{10}$ Farhan Asyhadi, Analisis Dampak Restrukturasi Kredit Terhadap Pembiayaan (Leasing) pada Masa Pandemi Corona Virus Disease 2019, Jurnal Justisi Hukum, Vol. 5, No, 1, September 2020, p. 1

${ }^{11}$ Idri, Hadis Ekonomi Dalam Perspektif Hadis Nabi,(Jakarta: Prenadamedia, 2015), p. 41.
} 


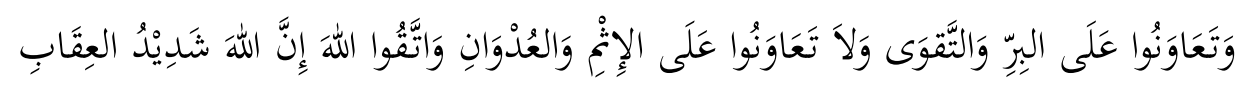

Artinya :"...Dan tolong menolonglah kamu dalam mengerjakan kebajikan dan taqwa, dan jangan tolong menolong dalam berbuat dosa dan pelangggaran. Dan bertaqwalah kamu kepada Allah Swt, sesungguhnya Allah amat berat siksaNya"

Dari ayat diatas Islam mengajarkan manusia untuk saling melakukan tolongmenolong, sebagaimana konsep dari manusia sendiri yang tidak bisa mencukupi kebutuhannya sendiri, tetapi juga membutuhkan bantuan atau pertolongan dari sesama. Islam juga mengatur agar tidak sampai terjadi hal-hal yang tidak diinginkan atau menyimpang. Sebagaimana dalam QS Al-Baqarah ayat 275 yang berbunyi:

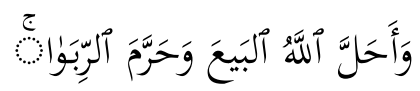

Artinya: "...Allah telah menghalalkan jual beli dan mengharamkan riba...".

Ayat tersebut menerangkan bahwasanya Allah telah menghalalkan kegiata jualbeli dan juga mengharamkan adanya riba, jual-beli yang dihalalkan adalah yang bersih dan tidak mengandung unsur riba dan juga memenuhi syarat serta rukun praktik jual-beli. Akan tetapi pada praktiknya sering ditemui dalam keseharian manusia, tidak dapat terhindar dari permaslahan yang berhubungan dengan kegiatan jual beli, seperti halnya jual-beli dengan sistem kredit, yang mana akan dapat berujung pada hutang yang dibayarkan pada tenggang waktu tertentu. Dengan melakukan jual-beli yang selalu berkembang dengan pemikiran yang kreatif seperti adanya jual-beli angsuran tersebut, yang mana berkaitan dengan harga yang digunakan, cara pembayaran, serta model jual beli yang dipilih, serta yang terpenting adalah sistem jual beli yang dipraktikkan masih dalam jalur ketetapan syariat sehingga manusia terhindar dari risiko dosa, merugikan orang lain, dan kesulitan-kesulitan yang lainnya.

Model jual-beli angsuran adalah jual-beli yang dilakukan dikalangan masyarakat yang berkaitan dengan waktu pembayaran dilakukan dengan cara kredit, jual beli ini banyak dilakukan masyarakat di zaman modern ini. Cara kredit telah terbukti banyak diminati oleh masyarakat agar dapat memenuhi kebutuhannya. Praktek ini memiliki aspek keuntungan dan juga mudharat. Aspek keuntungannya berupa ekonomi, kepemilikan barang dapat lebih cepat diperoleh, barang yang diinginkan cepat untuk dimiliki dan dinikmati oleh konsumen dan kemampuan angsuran dapat disesuaikan dengan kemampuannya dalam membayar cicilan hutangnya. Sedangkan sisi mudharatnya, harga yang dibayarkan oleh konsumen lebih tinggi seiring bertambahnya masa kredit. $^{12}$

\footnotetext{
${ }^{12}$ Khairunnisak Silaen, Kredit produk Kosmetik Tanpa Kejelasan Jangka Waktu Pembayaran Perspektif Mazhab Syafi'l Syafi'l (Studi Kasus di Desa Tanjung Gusta Kecamatan Sunggal Kabupaten Deli Serdang)", Skripsi UIN Sumatera Utara, 2019.
} 


\section{Negosiasi}

Tata cara menyelesaikan sengketa perbankan syariah telah secara langsung diatur oleh perundang-undangan antara lain; 1). Pasal 49 UU No.3 Tahun 2006 tentang Peradilan Agama, menjelaskan bahwa peradilan agama memiliki tugas dan kewenangan untuk melakukan pemeriksaan, memutus, dan menyelesaikan perkara ditingkat pertama antara masyarakat yang beragama Islam di bidang: perkawinan, waris, wasiat, hibah, wakaf, zakat, infaq, sedekah, dan juga ekonomi syariah. pada pasal 49 huruf i dijelaskan bahwa "ekonomi syariah", adalah perbuatan yang dilakukan menurut prinsip syariah antara lain meliputi perbankan syariah, lembaga keuangan mikro syariah, asuransi syariah, pembiayaan syariah, pegadaian syariah, dan bisnis syariah. $\left.{ }^{13} 2\right)$. Pasal 55 UU No. 21 Tahun 2008 tentang Perbankan Syariah, menjelaskan bahwa menyelesaikan sengketa terkait perbankan syariah dapat ditempuh dengan memilih jalur antara lain; dilakukan di Pengadilan Agama, dan diluar Pengadilan Agama dalam hal para pihak telah mengadakan perjanjian melalui akad penyelesaian sengketa selain Pengadilan Agama dengan syarat penyelesaian sengketa tersebut dengan cara yang tidak bertentangan dengan prinsip syariah. Adapun upaya-upaya penyelesaian sengketa diluar Pengadilan Agama antara lain; musyawarah, mediasi perbankan, melalui Badan Arbitrase Syariah Nasional (BASYARNAS), dan melalui pengadilan dalam lingkungan Pengadilan Umum. ${ }^{14} 3$ ). Putusan Bank Indonesia No. 9.19/PBI/2007 tentang pelaksanaan prinsip syariah dalam kegiatan penghimpunan dana penyaluran serta pelayanan jasa bank syariah. Dijelaskan dalam pasal ini jika sengketa antara bank dengan nasabah diselesaikan melalui jalan musyawarah, jika musyawarah tidak mencapai mufakat maka penyelesaian sengketa dapat dilakukan melalui jalan mediasi termasuk mediasi perbankan sendiri. Jika mediasi tidak dapat mencapai mufakat, maka penyelesaian diadakan dengan mekanisme arbitrase syariah atau melalui lembaga peradilan yang telah diatur oleh undang-undang. ${ }^{15}$

Maraknya kegiatan bisnis syariah yang tidak memungkinkan untuk terhindar dari sengketa (dispute/difference) antara para pihak yang berkontrak baik kontrak pada kemitraan ataupun jual beli. Adapun penyeleaian sengketa dapat dilakukan melalui jalur litigasi (pengadilan) ataupun non litigasi (alternative dispute resolution), bisa dipilih oleh pihak-pihak yang berselisih. Penyelesaian sengketa dengan cara litigasi ataupun non litigasi memiliki kelebihan dan juga kekurangannya masing-masing namun yang paling penting yaitu bagaimana cara menyelesaikan sengketa dengan cepat, sederhana dan juga biaya yang ringan. Proses menyelesaikan perkara perdata idealnya dapat diselesaikan dalam waktu maksimal enam bulan tetapi dapat juga berakhir setelah memakan waku lama

\footnotetext{
${ }^{13}$ Rika Delfa Yona, Penyelesaian Sengketa Perbankan Syariah di Indonesia,Jurnal Economic:Jurnal Ekonomi dan Hukum Islam, Vol.4, No.1 2014.,p. 63.

14 Ibid, p. 64.

${ }^{15}$ Ibid, p. 65.
} 
misalnya bertahun-tahun lamanya, hal ini dapat berakibat tidak terjaminnya transparansi, kepastian dan prediktabilitas. Saat ini fugsi peradilan juga dianggap kurang efektif dan efisien bagi para pelaku usaha bisnis. Pengadilan memperoleh beban yang terlampau berat (overloaded), boros waktu, biaya mahal, dan juga kurang tanggap terhadap kepentingan umum atau terlalu formalistik dan teknis. Hal ini juga diperburuk dengan putusan pengadilan yang selalu bersifat win-lose solution atau terdapat pihak yang menang dan kalah atas penyelesaian sengketa sehingga menjadi beban bagi pelaku usaha bisnis karena hubungan kedua belah pihak bisa terputus dan bermusuhan.

Adapun penyelesaian sengketa non litigasi merupakan bentuk consensus yang memiliki persamaan, yakni cara penyelesaian sengketa dengan kooperatif atau kompromi untuk mendapatkan solusi yang bersifat win win solution dengan cara memberikan kelonggaran untuk hak-hak tertentu dengan berasaskan timbalbalik, sedangkan perbedaannya hanya pada model cara penyelesaiannua. Adapula bentuk penyelesaian sengketa non litigasi yang sudah lama dikenal dan dipraktikan dalam sengketa perdata di dunia bisnis adalah negoisasi. Negoisasi adalah fact of life atau keseharian. Semua orang bisa melakukan proses ini untuk mendapatkan apa yang diinginkan dengan cara sama-sama mufakat. Negoisasi yang berasal dari bahasa Inggris yaitu, "negotiation", yang berarti perundingan, berunding, bermusyawarah atau bermufakat. ${ }^{16}$ Negoisasi ini dilakukan oleh para pihak yang bersengketa secara langsung, didalam konteks sengketa bisnis para pihak ini bisa karyawan dari badan usaha ataupun lembaga keuangannya.

Menurut Erman ada beberapa petunjuk untuk dapat mencapai suksesnya negoisasi hingga dapat menghasilkan keputusan yang mufakat, antara lain; ${ }^{17} 1$ ) jangan mengusulkan sesuatu yang jika hal tersebut diusulkan, tidak dapat diterima secara pribadi, jika tidak dapat diterima pastilah pihak lain juga tidakakan menerimanya. Tujuan dalam negoisasi haruslah dapat diterima oleh semua pihak. 2). Tidak dengan paksaan, dalam negoisasi tidak ada satu pihak pun yang ingin dipaksa. Jadi buatlah kedua belah pihak bersama-sama mengendalikan negoisasi (sharing of control) dan terus berkomunikasi. Pada saat komunikasi hendaknya menjawab apa yang ditawarkan oleh pihak lain. Umpan balik yang positif jika setuju dan sebaliknya. 3). Kesabaran adalah cara agar negoisasi dapat berjalan lancar. Sabar namun tidak bertele-tele dan segera diungkapkan dengan jelas. Jika menyetujui maka segera ungkapkan dengan kata setuju sehingga langkah ini mempercepat penyelesaian sengketa, 4) Tidak ada yangmengetahuiapa yang akan dilakukan oleh pihak lawan atau bagaimana nanti masalah dapat diatasi. Sehingga harus selalu tenang dan berfikiran rasionalis dan positif sehingga dapat menemukan ide-ide yang baik pula dalam menyelesaikan masalah.

\footnotetext{
${ }^{16}$ Bambang Sutiyoso, Penyelesaian Sengketa Bisnis, (Bandung:Citra Media, 2006), p. 41.

${ }^{17}$ Erman R, Penyelesaian Sengketa Alternatif,(Depok: Universitas Indonesia Press, 2005), p. 47-48.
} 
Penyelesaian masalah melalui jalur negoisasi harus dilakukan dalam bentuk pertemuan yang dilakukan secara langsung oleh para pihak yang bersengketa tanpa adanya orang ketiga sebagai penengah, dalam penyelesaian sengketa. ${ }^{18}$ Sedangkan menurut Abdul Manan dalam negoisasi memungkinkan para pihak untuk tidak secara langsung hadir dalam bernegosiasi yakni bisa dengan cara mewakilkan kepentingannya kepada masing-masing negosiator yang sudah ditunjuk untuk melakukan negosiasi dengan kompromistis dan saling melepas atau memberikan kelonggaran-kelonggaran demi untuk tercapainya penyelesaian secara damai. ${ }^{19}$

\section{Restukturisasi}

Restrukturisasi atau biasa yang disebut juga dengan penyelamatan pembiayaan adalah istilah teknis yang digunakan di kalangan perbankan terhadap upaya dan langkah yang dilakukan bank sebagai upaya mengatasi masalah pembiayaan yang sedang dihadapi oleh nasabah kredit macet.

Dalam PBI No. 8/12/PBI/2006 tentang laporan berkala bank umum, pasal 2 ata 4 huruf (g) menjelaskan; restruturisasi pembiayaan adalah upaya perbaikan yang dilakukan bank dalam kegiatan pembiayaan, piutang, dan atau ijarah terhadap debitur yang mengalami kesulitan untuk memenuhi kewajibannya". 20 Selanjutnya dalam PBI No.8/21/PBI/2006 tentang panilaian kualitas aktiva bank umum yang melaksanakan kegiatan usaha berdasarkan prinsip syariah, pasal 1 butir 31: restrukturisasi pembiayaan adalah upaya perbaikan yang dilakukan bank dalam kegiatan penyediaan dana terhadap nasabah yang mengalami kesulitan untuk memenuhi kewajibannya dengan mengikuti ketentuan yang berlaku yakni fatwa Dewan Syariah Nasional dan Standar Akuntansi Keuangan yang berlaku bagi bank syariah. ${ }^{21}$

Dasar hukum restrukturisasi pembiayaan adalah sebagai berikut:22

a. Undang-undang

Dasar hukum restrukturasi pembiayaan dapat ditemukan didalam pasal 36 UU No. 21 Tahun 2008 tentang Perbankan Syariah yang menjelaskan bahwa "dalam menyalurkan pembiayaan dan melakukan kegiatan usaha lainnya, Bank Syariah dan Unit Usaha Syariah wajib menempuh cara-cara yang tidak

\footnotetext{
${ }^{18}$ Raditya Tatag Sidiartama, dkk. Choice of Forum Penyelesaian Sengketa Dalam Klausual Akad Perbankan Syariah, Jurnal Diponegoro Law, Vol 5, No.4 Tahun 2016, p. 6.

${ }^{19}$ Abdul Manan, Hukum Ekonomi Syariah dalam Perspektif Kewenangan Peradilan Agama, (Jakarta: Kencana, 2014), p. 446.

${ }^{20} \mathrm{PBI}$ No. 8/ 12/PBI/2006

${ }^{21}$ Nur Dinah Fauziah, dkk, Restrukturisasi Sebagai Salah Satu Upaya Penyelesaian Pembiayaan Bermasalah di Bank Syariah, Jurnal Al-'Adalah: Jurnal Syariah dan Hukum Islam, Vol. 3, No.3, 2018.

22 Ummi Kalsum dan Rahmi, Restrukturisasi Pembiayaan Murabahah Bermasalah (Studi Pada BNI Syariah Cabang Kendari), Li Falah: Jurnal Studi Ekonomi dan Bisnis Islam, Vol. 2, No. 2, 2017, p. 61
} 
merugikan bank syariah dan atau Unit Usaha Syariah dan kepentingan nasabah yang mempercayakan dananya".

b. Fatwa Dewan Syariah Nasional

Dasar hukum restrukturisasi dapat ditemukan di fatwa Dewan Syariah Nasional Nomor. 48/DSN-MUI/II/2005 tentang penjadwalan kembali tagihan murabahah.

c. Peraturan Bank Indonesia

Restrukturisasi diatur dalam Peraturan Bank Indonesia Nomor: 10/18/PBI/2008 tentang Restrukturisasi Pembiayaan bagi Bank Syariah dan Unit Usaha Syariah dan juga Surat Edaran Bank Indonesia No. 10/34DPbs, tentang Restrukturisasi Pembiayaan bagi Bank Umum Syariah dan Unit Usaha Syariah.

\section{Metode Penelitian}

Penelitian ini merupakan penelitian field research atau penelitian lapangan, yakni penelitian sosial yang dilakukan dalam kehidupan sebenarnya. ${ }^{23}$ Objek penelitian yang dilakukan mengenai penyelesaian kredit macet pada jual beli angsuran yang dilakukan di BMT IKPM Ponorogo, sedangkan subjek dari penelitian sebenarnya adalah semua pihak yang terkait dalam kontrak pembiayaan jual beli angsuran. Pada penelitian ini sumber data yang digunakan dibagi menjadi dua yaitu, data primer dan data sekunder. Dalam hal ini adalah wawancara yang dilakukan terhadap orangorang yang menjadi pengurus di BMT IKPM Ponorogo serta dokumen-dokumen penting di lapangan.

Teknik pengumpulan data dan keterangan yang diperlukan, penulis menggunakan tiga teknik pengumpulan data utama yang biasa digunakan dalam kajian lapangan secara kualitatif, yaitu: observasi, wawancara (interview), dan dokumen. Ketiga teknik ini umumnya disebut dengan istilah triangulasi. ${ }^{24}$ Selanjutnya data-data akan dianalisis secara deskriptif, yakni penelitian yang menghasilkan data deskripsi atau paparan secara rinci berupa kata-kata tertulis atau lisan dari orang-orang dan perilaku yang dapat diamati dengan metode yang telah ditentukan. ${ }^{25} \mathrm{~F}$ akta-fakta yang dikumpulkan adalah dari praktik jual beli angsuran yang ada pada produk pembiayaan di BMT IKPM Ponorogo, penulis memulai memberikan pemecahan persoalan yang bersifat umum pada penyelesaian permasalahan yang bersifat umum, melalui rumusan masalah dari observasi awal yang telah dilakukan di BMT IKPM Ponorogo. Pada penelitian ini dilakukan di BMT IKPM Ponorogo sehingga dapat

\footnotetext{
${ }^{23}$ Mardalis, Metode Penelitian,(Jakarta: Bumi Aksara, 1995), p. 28.

${ }^{24}$ Merriam, S.B., Case study research in education: A qualitative approach. 3 rd Ed (San Francisco: Jossey-Bass Publishers, 1990), p. 73

${ }^{25}$ Burhan Bungin, Metodologi Penelitian Sosial: Format-format Kuantitatif dan Kualitatif, (Surabaya: Airlangga University Press, 2001), p. 143.
} 
ditemukan pemahaman terhadap pemecahan masalah dari rumusan masalah yang telah ditentukan, selanjutnya ditinjau dari teori-teori yang ada dalam hukum Islam untuk menguraikan bagaimana implementasi penyelesaian kredit macet pada jual beli angsuran di BMT IKPM Ponorogo.

\section{Hasil dan Pembahasan}

Praktik produk pembiayaan jual-beli angsuran yang dilakukan di BMT IKPM sebagai lembaga keuangan Islam non-bank yaitu dengan akad murabahah. Implementasi akad murabahah dengan sistem margin ditentukan di awal akad. ${ }^{26}$

Ada beberapa tipe dalam penerapan akad murabahah dalam praktik kredit syariah yang semuanya dapat dibagi menjadi beberapa kategori besar, antara lain:

1. Tipe konsisten pada fiqih muamalah. Dalam tipe ini bank membeli terlebih dahulu barang yang akan dibeli oleh nasabah setelah ada perjanjian sebelumya. Setelah barang dibeli atas nama bank kemudian dijual kepada nasabah dengan harga perolehan yang ditambah dengan margin atau keuntungan sesuai kesepakatan para pihak. Pembayaran dapat dilakukan secara tunai atau tangguh yang berupa angsuran dalam jangka waktu tertentu. ${ }^{27}$

2. Tipe yang hampir mirip dengan yang pertama tetapi perpindahan kepemilikan langsung dari pihak supplier kepada nasabah, sedangkan pembayaran dilakukan oleh bank secara langsung kepada supplier. Nasabah selaku pembeli kemudian menerima barang setelah mengadakan perjajian terlebih dahulu dengan bank. Pembelian ini dilakukan secara tunai oleh bank, sedangkan nasabah melakukan pembayaran kepada bank secara tangguh atau cicilan. Biasanya transaksi ini lebih mirip dengan konsep murabahah yang sebenarnya, tetapi rawan dalam masalah legal. ${ }^{28}$

3. Tipe yang ketiga ini sering sekali di lakukan oleh bank syariah. Bank melakukan akadmurabahah dengan nasabah dan pada saat yang sama mewakilkan nasabah untuk dapat membeli sendiri barang dari pihak supplier kemudian dana dikreditkan ke rekening nasabah, lalu nasabah menandatangani tanda terima uang. Tanda terima ini yang menjadi dasar bagi bank untuk menghindari klaim

\footnotetext{
${ }^{26}$ Wawancara, Ahmad Hisanuddin, Finance BMT IKPM

${ }^{27}$ Hadi Aksi, Kredit Murabahah Dalam Kitab Hadis Kutub al Tis'ah (Analisis Jual Beli Angsuran/Tangguh Dalam Hukum Syariah),Jurnal Hukum dan Pemikiran, Vol. 18 No.2 Desember 2018, p. 236

${ }^{28}$ Ada beberapa kasus ditemukan adanya klaim nasabah bahwa mereka tidak melakukah transaksi hutang dengan bank, sehingga bank kurang memiliki bukti secara legal meskipun nasabah telah menandatangani kontrak, tetapi nasabah tidak menerima bukti tanda terima nasabah menerima uang dari bank. Untuk menghindari hal yang demikian maka ketika bank dan nasabah menyetujui untuk melakukan transaksi jual beli/ murabahah makabank akan mentransfer pembayaran barang ke rekening nasabah kemudian didebet dengan persetujuan nasabah untuk ditransfer ke rekening supplier. (Nurhadi, Analisis Hukum Perikatan Klausul Akad Pembiayaan Murabahah bil Wakalah Nomor. 090/Murabahah/Pkb/V/2016 Bank Rakyat Indonesia Syariah. Tesis: Pascasarjana Universitas Islam Riau Pekanbaru 2016, 21).
} 
bahwa nasabah tidak berhutang kepada Bank karena tidak menerima uang sebagai sarana hutang secara langsung.

Tipe ketiga ini seyogyanya menyalahi aturan syariah jika bank mewakilkan nasabah untuk dapat membeli barang dari pihak ketiga, sedangkan akad jual beli murabahah telah dilakukan sebelum barang secara prinsip menjadi milik bank. Tipe jual beli angsuran yang dilakukan di BMT IKPM Ponorogo seperti pada tipe pertama, BMT memenuhi kebutuhan nasabah terlebih dahulu membeli barang atau jasa yang dibutuhkan nasabah, selanjutnya bank menjual ke nasabah dengan penentuan margin diawal akad. Selanjutnya nasabah melakukan pembayar kepada bank dengan sistem cicilan.

Proses penyelesaian sengketa di BMT IKPM Ponorogo lebih dominan dengan bentuk penyelesaian sengketa non litigasi yaitu dengan cara negosiasi. Pihak yang bersengketa langsung (nasabah jual beli angsuran macet di BMT IKPM Ponorogo) dengan karyawan BMT IKPM Ponorogo (finance). Ahmad Hisanuddin selaku Finance BMT IKPM Ponorogo menyebutkan: ${ }^{29}$

"Penyelesaian sengketa jual beli angsuran ini yang nyelesein adalah finance/marketing dari BMT Sendiri, marketing yang bertanggung jawab adalah yang membawa meraka melakukan kredit di BMT sampai selesai masa kredit mereka".

Penjelasan diatas merupakan bentuk tanggungjawab keberlangsungan operasional di BMT IKPM Ponorogo. Jadi nasabah yang akan melakukan pengajuan, sistem pembayaran, masa angsuran, penyelesaian sengketa kredit mecet, pelunasan jual beli angsuran ditangani oleh seorang finance. Pada penyelesaian sengketa yang dilakukan oleh Finance dan nasabah kredit macet dengan cara negosiasi secara langsung antara mereka, meskipun dalam pengajuan jual beli angsuran ini nasabah memberikan agunan kepada BMT, akan tetapi pihak BMT IKPM Ponorogo berusaha untuk tidak sampai menjual agunan tersebut, oleh karena itu pihak BMT melakukan negosiasi dengan nasabah untuk mendapatkan solusi mufakat yang bersifat win-win solution.

Penyelesaian sengketa yang dilakukan oleh BMT IKPM Ponorogo dengan nasabah kredit macet seperti penjelasan sebelumnya yakni ditangani oleh finance/marketing dari BMT IKPM, ini sebagai wakil dari BMT IKPM Ponorogo untuk melakukan negoisasi bertemu langsung dengan nasabah sehingga mendapatan kata sepakat pada kedua belah pihak yang tidak menimbulkan kerugian pada salah satu pihak. ${ }^{30}$

Adapun bentuk restrukturisasi yang dilakukan di BMT IKPM Ponorogo yang bertujuan untuk menyelesaikan sengketa pembayaran jual beli angsuranmacet, proses dan manajemen yang diterapkan di BMT IKPM Ponorogo sebagai berikut;

\footnotetext{
${ }^{29}$ Wawancara, Ahmad Hisanuddin, Finance, September 2020.

${ }^{30}$ Wawancara, Ahmad Hisanuddin, Finance, September 2020.
} 
1. Rescheduling (Penjadwalan Kembali), yakni merubah jadwal pembayaran angsuran nasabah, baik rentang waktu tanpa menambahkan sisa kewajiban yang harus dibayarkan nasabah kepada pihak BMT. Rescheduling di BMT ada dua bentuk yakni, a). Penjadwalan kembali angsuran disertai dengan perpanjangan waktu membayar. Pihak BMT akan memberikan kelonggaran rentang waktu kepada nasabah supaya dapat memenuhi kewajibannya. b). Penjadwalan kembali angsuran tanpa memberikan tambahan waktu sehingga rentang waktu pembiayaan tidak berubah, hanya saja BMT memberikan kelonggaran jumlah angsuran yang tersisa dan dapat diangsur sesuai dengan kesepakatan kedua belah pihak. ${ }^{31}$

2. Reconditioning (Persyaratan kembali), yakni perubahan syarat pembiayaan sebagian ataupun seluruhnya. Recondioning dapat dilakukan dengan cara merubah jadwal pembayaran, jumlah angsuran, jangka waktu ataupun pemberian potongan. ${ }^{32}$ Pada BMT IKPM Ponorogo pelaksanaan Reconditioning tergantung dengan kebutuhan dari nasabah dan negoisasi dengan finance/marketing yang bertanggung jawab atas kelancaran angsuran BMT. Ada nasabah yang diberikan kelonggaran pembaharuan jadwal angsuran dan perubahan jangka waktu tanpa mengurangi jumlah nominal kewajiban nasabah membayar angsuran. ${ }^{33}$

3. Restructuring (penataan Kembali), yakni merubah persyaratan pengajuan hutang yang tidak terbatas pada rescheduling dan reconditioning dapat dilakukan melalui dana fasilitas pembiayaan bank, konversi akad pembiayaan, konversi pembiayaan menjadi surat berharga syariah berjangka waktu menengah, dan konversi pembiayaan menjadi penyertaan modal sementara pada perusahaan nasabah. Untuk restructuring yang dipraktikkan di BMT IKPM Ponorogo yakni tetap menggunakan akad yang sama, karena jika adanya konversi akad yang dilakukan hal tersebut kurang tepat dan dipasikan adanya kesalahan dalam menganalisis pemberian pembiayaan sebelum pembiayaan tersebut disetujui. ${ }^{34}$

Adapun semua traksaksi restrukturisasi yang dilakukan di BMT IKPM Ponorogo selalu melakukan negosiasi dengan nasabah dalam menyelesaikan permasalahan angsuran yang macet dan mencari solusi bersama untuk mencapai kebaikan dan kelancaran sehingga solusi ini bersifat win win solution yang efisian waktu dan biaya. Restrukturisasi adalah suatu wadah yang difasilitasi oleh BMT IKPM Ponorogo untuk bernegoisasi dengan nasabah yang mengalami permasalahan kesulitan dalam menyelesaiakan tanggung jawab pembayaran jual beli angsuran dengan cara negoisasi yang bersifat tidak merugikan salah satu pihak. Penyelesaian sengketa jual beli angsuran di BMT IKPM Ponorogo semuanya dapat diselesaikan dengan cara

\footnotetext{
${ }^{31}$ Wawancara, Ahmad Hisanuddin, Finance, September 2020.

${ }^{32}$ Muhammad Rifqi Hidayat dan Parman Komarudin, Penanganan Non Performing Finance dalam Akad Musyarakah di Bank Kalsel Syariah, Jurnal At-Taradhi, Vol. 9 No.1 Juni 2018, p. 5.

${ }^{33}$ Wawancara, Ahmad Hisanuddin, Finance, September 2020.

${ }^{34}$ Wawancara, Ahmad Hisanuddin, Finance, September 2020.
} 
restrukturisasi yang ditentukan dengan negoisasi antara nasabah kredit macet dengan finance/marketing selaku wakil dari lembaga BMT IKPM Ponorogo serta tidak sampai pada penyeleaian sengketa yang bersifat memaksa seperti penyitaan barang jaminan atau sampai menjual jaminan. ${ }^{35}$ Sebagaimana dalam QS al Maidah ayat 2, yang berbunyi; ${ }^{36}$

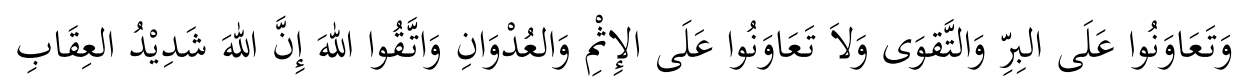

Artinya :“...Dan tolong menolonglah kamu dalam mengerjakan kebajikan dan taqwa, dan jangan tolong menolong dalam berbuat dosa dan pelangggaran. Dan bertaqwalah kamu kepada Allah Swt, sesungguhnya Allah amat berat siksaNya"

Surah al Maidah ayat 2 tersebut dapat menjelaskan bahwa restrukturisasi merupakan salah satu upaya menolong nasabah yang mengalami kesulitan pembayaran dengan cara negoisasi mufakat untuk menemukan solusi atas kesulitan nasabah dalam melakukan pembayaran sehingga nasabah tetap bisa bertanggung jawab dengan kewajibannya kepada BMT IKPM Ponorogo. Adanya negoisasi pada restrukturisasi maka proses restrukturisasi nasabah tidak terpaksa atas ketetapan dan solusi yang di hasilkan sehingga nasabah juga merasa terbantu untuk melaksanakan kewajibannya. Sebagaimana akad awal yang telah dilakukan oleh nasabah dalam melakukan jual beli angsuran dengan BMT, nasabah melakukan akad dengan sukarela dan tanpa paksaan, oleh karena itu dalam penyelesaian sengketa dengan adanya negoisasi ini bertujuan sebagaimana transaksi jual beli awal yang pelaksanaannya dengan sukarela dan tanpa paksaan.

\section{Penutup}

Berdasarkan pembahasan diatas, maka dapat diambil kesimpulan bahwa restrukturisasi yang dilakukan di BMT IKPM Ponorogo selalu melakukan negosiasi dengan nasabah dalam menyelesaikan permasalahan angsuran yang macet dan mencari solusi bersama untuk mencapai kebaikan dan kelancaran sehingga solusi ini bersifat win win solution yang efisian waktu dan biaya. Restrukturisasi adalah suatu wadah yang difasilitasi oleh BMT IKPM Ponorogo untuk bernegoisasi dengan nasabah yang mengalami permasalahan kesulitan dalam menyelesaikan tanggung jawab pembayaran jual beli dengan sistem kredit, cara ini dianggap tidak merugikan salah satu pihak. Adapun penyelesaian sengketa dengan cara restrukturisasidilaksanakan melalui Rescheduling (penjadwalan kembali), Reconditioning (persyaratan kembali), Restructuring (penataan kembali). Upaya penyelesaian sengketa nasabah kredit macet di BMT IKPM Ponorogo cukup pada tahap ini karena dengan negosiasi di tahap restukturisasi dapat meminimalisir

\footnotetext{
${ }^{35}$ Wawancara, Ahmad Hisanuddin, Finance, September 2020.

${ }^{36} \mathrm{QS}$, al Maidah (5): 2
} 
penyelesaian sengketa dengan menjual agunan atau hingga ke penyelesaian sengketa lewat jalur litigasi.

Disarankan untuk peneliti selanjutnya agar dapat meneliti cara-cara lain selain restrukturasi sebagai jalan penyelesaian pembiayaan bermasalah, agar permasalahan pembiayaan bermasalah tidak selalu diselesaikan lewat jalur litigasi (peradilan).

\section{Daftar Pustaka}

Aksi, Hadi. (2018).Kredit Murabahah Dalam Kitab Hadis Kutub al Tis'ah (Analisis Jual Beli Angsuran/Tangguh Dalam Hukum Syariah).Jurnal Hukum dan Pemikiran, Vol. 18 No.2

Asyhadi, Farhan. (2020). Analisis Dampak Restrukturasi Kredit Terhadap Pembiayaan (Leasing) pada Masa Pandemi Corona Virus Disease 2019. Jurnal Justisi Hukum, Vol. 5, No, 1.

Bungin, Burhan.(2001). Metodologi Penelitian Sosial: Format-format Kuantitatif dan Kualitatif, Surabaya: Airlangga University Press.

Djamil, (2012). Penyelesaian Pembiayaan Bermasalah di Bank Syariah. Jakarta: Sinar Grafika.

Fauziah, Nur Dinah dkk, (2018).Restrukturisasi Sebagai Salah Satu Upaya Penyelesaian Pembiayaan Bermasalah di Bank Syariah.Jurnal Al-'Adalah: Jurnal Syariah dan Hukum Islam, Vol. 3, No.3.

Hadi, Sutrisno.(1975). Metodologi Research.Yogyakarta: Gajah Mada University.

Ibrahim. (2015). Metodologi Penelitian Kualitatif. Bandung: Alfabeta.

Idri, (2015). Hadis Ekonomi Dalam Perspektif Hadis Nabi. Jakarta: Prenadamedia.

Indrintoro, Nur. (2002). Metodologi Penelitian Bisnis: untuk Akuntansi dan Manajemen. Yogyakarta: BPFE.

Khairunisa, Madona dan Musrifah. (2020). Penyelesaian Pembiayaan Bermasalah pada Bank Syariah. Jurnal IBF: Islamic Business and Finance, Vol. 1, No. 1.

Lidyah,Rinda dkk.(2019). Pengujian Financing To Deposit Ratio Sebagai Mediasi Antara Pembiayaan Non Performing Financing dan Biaya Operasional TerhadapLaba Pada Bank Umum Syariah di Indonesia,Jurnal I-Finance Vol.05, No.2.

Kholiq, Abdul dan Rahmawati, Rizqi. (2020). Dampak Implementasi Restrukturasi Pembiayaan Terhadap Likuiditas Bank Syariah pada Situasi Pandemi Covid-19. el Barka: Journal of Islamic Economic and Business, Vol. 3, No. 2.

Manan, Abdul. (2014). Hukum Ekonomi Syariah dalam Perspektif Kewenangan Peradilan Agama. Jakarta: Kencana.

Mardalis.(1995). Metode Penelitian. Jakarta: Bumi Aksara. 
Merriam, S.B., (1990), Case study research in education: A qualitative approach. 3 rd Ed, San Francisco: Jossey-Bass Publishers.

Muhammad Rifqi Hidayat dan Parman Komarudin, Penanganan Non Performing Finance dalam Akad Musyarakah di Bank Kalsel Syariah, Jurnal At-Taradhi, Vol. 9 No.1 Juni 2018.

Otoritas Jasa Keuangan (OJK).Statistik Perbankan Syariah Januari 2020

R, Erman. (2005).Penyelesaian Sengketa Alternatif. Depok: Universitas Indonesia Press.

Sidiartama, Raditya Tatag dkk. (2016). Choice of Forum Penyelesaian Sengketa Dalam Klausual Akad Perbankan Syariah.Jurnal Diponegoro Law, Vol 5, No.4.

Silaen, Khairunnisak.(2019). Kredit Produk Kosmetik Tanpa Kejelasan Jangka Waktu Pembayaran Perspektif Mazhab Syafi'l Syafi'l (Studi Kasus di Desa Tanjung Gusta Kecamatan Sunggal Kabupaten Deli Serdang)", Skripsi UIN Sumatera Utara.

Simamora, Ucok Parulianth.(2017). Restrukturisasi Perjanjian Kredit Dalam Perhatian Khusus (Studi Kasus Pada PT.Bank Rakyat Indonessia, TBK Cabang Bandar Jaya Unit Haduyang Ratu),Jurnal Cepalo, Vol 1 No. 1.

Sutiyoso, Bambang. (2006). Penyelesaian Sengketa Bisnis. Bandung:Citra Media.

Yona, Rika Delfa.(2014). Penyelesaian Sengketa Perbankan Syariah di Indonesia.Jurnal Economic:Jurnal Ekonomi dan Hukum Islam, Vol.4, No.1.

PBI No. 8/ 12/PBI/2006

PBI No.7/3/PBI/2005 